\title{
SARS-Cov-2 (human) and COVID-19: Primer 2020
}

\author{
Gayatri Ramakrishna ${ }^{1}$. Pradeep Kumar ${ }^{1}$. Savera Aggarwal ${ }^{1} \cdot$ Mojahidul Islam $^{1} \cdot$ Ravinder Singh $^{1}$. \\ Rakesh K. Jagdish ${ }^{2} \cdot$ Nirupma Trehanpati $^{1}$
}

Received: 9 April 2020 / Accepted: 9 April 2020 / Published online: 24 April 2020

(c) Asian Pacific Association for the Study of the Liver 2020

Gayatri Ramakrishna

rgayatri@ilbs.in

Nirupma Trehanpati

trehanpati@gmail.com

1 Molecular and Cellular Medicine, Institute of Liver and Biliary Sciences, Delhi, India

2 Department of Hepatology, Institute of Liver and Biliary Sciences, Delhi, India 


\section{SARS-Cov-2 (human) , COVID-19 and Covidism: Primer 2020}

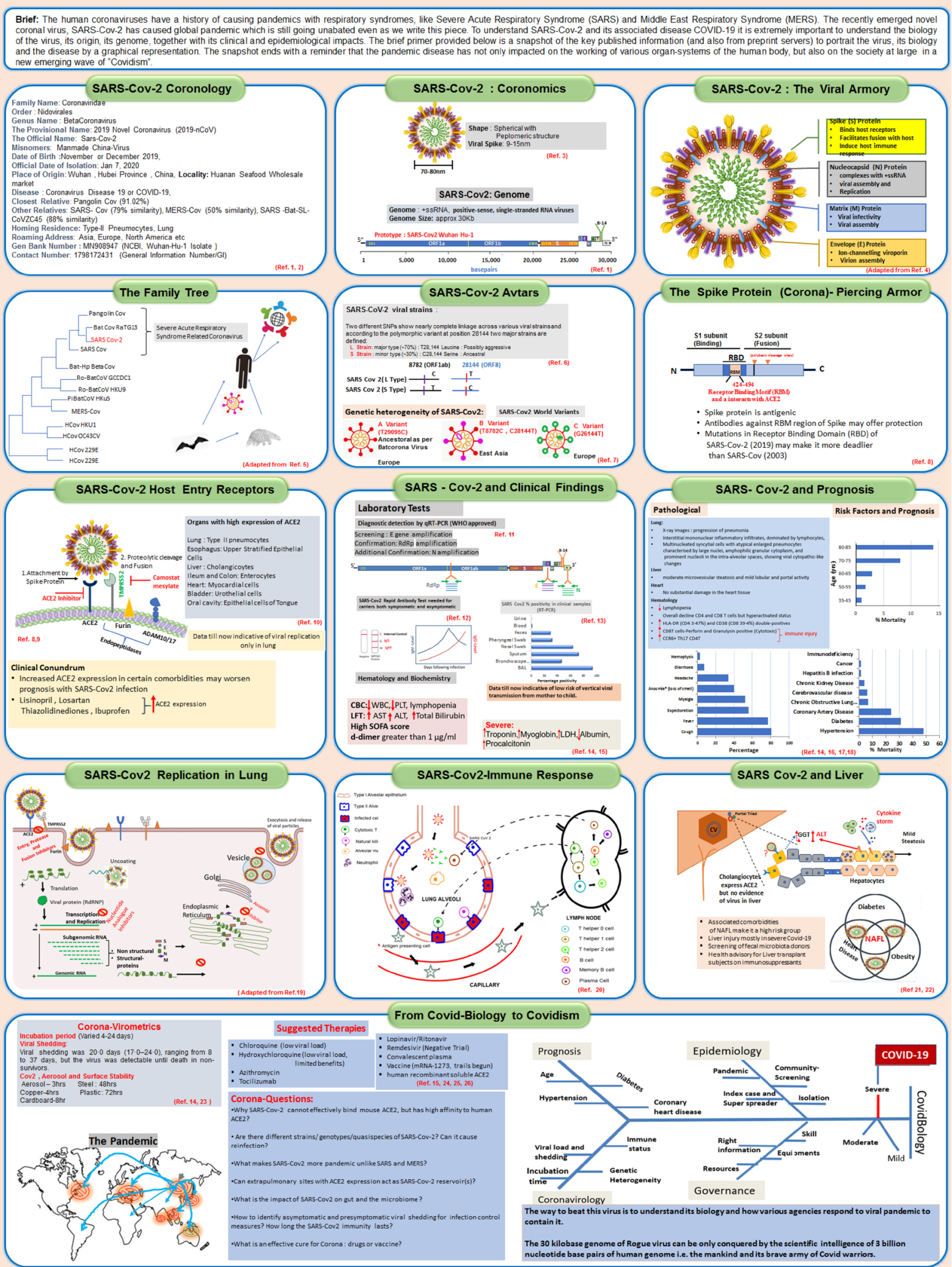




\section{References}

1. Lu R, Zhao X, Li J, Niu P, Yang B, Wu H, et al. Genomic characterisation and epidemiology of 2019 novel coronavirus: implications for virus origins and receptor binding. Lancet. 2020;395(10224):565-74.

2. Zhang $\mathrm{T}$, Wu Q, Zhang $\mathrm{Z}$. The Probable Pangolin origin of SARS Cov 2 associated with Covi19 outbreak. Curr Biol. 2020;30:1346-51.

3. Prasad P, Potdar V, Cherian S, et al. First image of coronavirus causing Covid-19 via TEM. Indian J Med Res. 2020. https://doi. org/10.4103/ijmr.IJMR_577_20.

4. Zumla A, Chan JF, Azhar EI, et al. Coronaviruses-drug discovery and therapeutic options. Nat Rev Drug Discov. 2016;15(5):327-47.

5. Gorbalenya AE, Baker SC, Baric RS, et al. The coronaviridae study group of the international committee on taxonomy of viruses. The species Severe acute respiratory syndrome-related coronavirus: classifying 2019-nCoV and naming it SARS-CoV-2. Nat Microbiol. 2020;5(4):536-44.

6. Tang X, Wu C, Li X, Song Y, Yao X, et al. On the origin and continuing evolution of SARS-CoV-2. Natl Sci Rev. 2020. https ://doi.org/10.1093/nsr/nwaa036.

7. Forster P, Forster L, Renfrew C, Forster M. Phylogenetic network analysis of SARS-CoV-2 genomes. Proc Natl Acad Sci USA. 2020. https://doi.org/10.1073/pnas.2004999117.

8. Hoffmann M, Kleine-Weber H, Schroeder S, et al. SARS-CoV-2 cell entry depends on ACE2 and TMPRSS2 and is blocked by a clinically proven protease inhibitor. Cell. 2020. https://doi. org/10.1016/j.cell.2020.02.052.

9. Ma Y, Huang Y, Wang T, et al. ACE2 shedding and furin abundance in target organs may influence the efficiency of SARSCoV-2 entry. 2020. chinaXiv:202002.00082v1

10. $\mathrm{Xu} \mathrm{H}$, Zhong L, Deng J, et al. High expression of ACE2 receptor of 2019-nCoV on the epithelial cells of oral mucosa. Int J Oral Sci. 2020;12(1):8. https://doi.org/10.1038/s41368-020-0074-x.

11. Corman VM, Landt O, Kaiser M, et al. Detection of 2019 novel coronavirus (2019-nCoV) by real-time RT-PCR. Euro Surveill. 2020. https://doi.org/10.2807/1560-7917.ES.2020.25.3.2000045.

12. Li Z, Yi Y, Luo X, et al. Development and clinical application of a rapid IgM-IgG combined antibody test for SARS-CoV-2 infection diagnosis. J Med Virol. 2020. https://doi.org/10.1002/jmv.25727.

13. Wang W, Xu Y, Gao R, et al. Detection of Sars-Cov-2 in different types of clinical specimens. JAMA. 2020. https://doi.org/10.1001/ jama.2020.3786.
14. Zhou F, Yu T, Du R, Fan G, Liu Y, Liu Z, et al. Clinical course and risk factors for mortality of adult in patients with COVID19 in Wuhan, China: a retrospective cohort study. Lancet. 2020;395(10229):1054-62.

15. Mark N. A seattle intensivists one pager on Covid-19. https:// www.onepagericu.com. 2020.

16. Xu Z, Shi L, Wang Y, et al. Pathological findings of COVID19 associated with acute respiratory distress syndrome. Lancet Respir Med. 2020;8(4):420-2. https://doi.org/10.1016/S2213 $-2600(20) 30076-X$

17. Guan W, Ni Z, Hu Y, Liang W, Ou C, He J, et al. Clinical characteristics of coronavirus disease 2019 in China. NEJM. 2020. https ://doi.org/10.1056/NEJMoa2002032.

18. Hopkins C, Kumar N. Loss of sense of smell as marker of COVID19 infection. www.entuk.org.

19. Cascella M, Rajnik M, Cuomo A, et al. NCBI Bookshelf, NBK554776PMID: 32150360.

20. Xu X, Gao X. Immunological responses against SARS-coronavirus infection in humans. Cell Mol Immunol. 2004;1(2):119-22.

21. Zhang C, Shi L, Wang FS. Liver injury in COVID-19: management and challenges. Lancet Gastroenterol Hepatol. 2020. https ://doi.org/10.1016/S2468-1253(20)30057-1.

22. Green CA, Quraishi MN, Shabir S, et al. Screening faecal microbiota transplant donors for SARS-CoV-2 by molecular testing of stool is the safest way forward. Lancet Gastroenterol Hepatol. 2020. https://doi.org/10.1016/S2468-1253(20).

23. van Doremalen N, Bushmaker T, Morris DH, et al. Aerosol and surface stability of SARS-CoV-2 as compared with SARS-CoV-1. N Engl J Med. 2020. https://doi.org/10.1056/NEJMc2004973.

24. Shen C, Wang Z, Zhao F, et al. Treatment of 5 critically ill patients with COVID-19 with convalescent plasma. JAMA. 2020. https:// doi.org/10.1001/jama.2020.4783.

25. Cohen J. Vaccine designers take first shots at COVID-19. Science. 2020;368(6486):14-6.

26. Monteil V, Kwon H, Prado P, et al. Inhibition of SARS-CoV-2 infections in engineered human tissues using clinical-grade soluble human ACE2. Cell. 2020. https://doi.org/10.1016/j. cell.2020.04.004 (epub ahead of print).

Publisher's Note Springer Nature remains neutral with regard to jurisdictional claims in published maps and institutional affiliations. 